\title{
RESTORASI MANAJEMEN WAKAF DARI TRADISIONAL MENUJU PROFESIONAL
}

\author{
Oleh: \\ Wawan Juandi \& Nawawi \\ Universitas Ibrahimy Situbondo, Indonesia \\ Universitas Ibrahimy Situbondo, Indonesia \\ nawawithabrani71@gmail.com \&wwnjuandi@gmail.com
}

\begin{abstract}
:
This study found that waqf is a form of worship that contains a distinct benefit. The distinction of waqf is that its object is permanent and its benefits continue to flow for the benefit of Islamic preaching and the economic improvement. Waqf is not only in the form of immovable objects but also includes all handy objects. This is in accordance with the words of the Prophet, "hold on to the point and give the result." So far, waqf has only been managed traditionally. It needs restoration so that becomes professional, and becomes a potential and useful asset for the benefit of Muslims. Waqf in the history has contributed to Muslim civilization. Waqf as a medium for Islamic preaching (dakwah), such as mosques, universities, and schools because it will becomes the glory of Islam as rahmatal lil 'alamin. Waqf also has a function as a medium for improving the economy of Muslims, because a very urgent need is property to meet the needs of life. Meanwhile, what people face today is poverty. One of them is waqf which is managed productively and professionally. Fourteen centuries ago, the Prophet said, "almost poverty has fallen into disbelief". Therefore, it is necessary to change the mindset or rejuvenate that Islam is not synonymous with poverty and backwardness. So, it is inappropriate for Muslims to live in an Islamic country in poverty even if they are kafir dzimmi (kafir who has the protection in Islamic country).
\end{abstract}

Keywords: Restorasi, Manajemen, Wakaf, Profesional, Dakwah, Ekonomi

\section{A. Pendahuluan}

Tujuan ajaran syariat Islam adalah demi tercapainya kemaslahatan manusia. Pada prinsipnya hukum Islam berpegang pada prinsip "jalb almashâlih wa dar'u al-mafâsid" (menjga kemaslahatan dan menolak kerusakan) ${ }^{1}$. Sedangkan tujuan hukum Islam telepasa dari tiga pokok, yaitu menjaga maslahat dharûriyyat, maslahat hajiyât, dan maslahat

${ }^{1}$ Izzuddin bin Abdusalam, Qawa'id al-Ahkam, (Beirut: Dar al Fikr, 1985) Juz II, 99. 
tahsiniyât. Agama Islam menjaga kemaslahatan dharûriyat dengan memberikan kebebasan untuk melaksanakan praktek-praktek ibadah dan ketentuan hukum ${ }^{2}$. Dalam hal ini wakaf menempati urutan ketiga dari maslahat yang ditawarkan Islam, yaitu maslahat tahsihiyyat.

Menurut al-Dahlawi bahwa wakaf mengandung kemaslahatan yang tidak dijumpai dalam sedekah yang lain, sebab kadangkala ada orang menggunakan hartanya di jalan Allah, tetapi pada akhirnya habis bendanya. Padahal masih banyak orang lain yang membutuhkannya. Oleh karena itu, tidak ada sedekah yang lebih baik dan bermanfaat bagi orangorang miskin dan ibnu sabil kecuali harta wakaf yang manfaatnya terus berkembang dan bendanya tetap permanen ${ }^{3}$.

Wakaf merupakan salah satu bentuk ibadah, yang nilainya lebih dominan pada ibadah sosial. Ini berarti juga merupakan salah stu jenis dari beberapa jenis ibadah serupa, seperti amal shalih, shadaqah, infaq dan lainnya: yang kesemuanya itu merupakan bentuk charity (charity table endowment). Dalam fikih klasik, wakaf biasanya diharuskan mengandung tiga syarat: (a) barang yang diwakafkan itu berupa barang tetap yang dapat diambil manfaatnya, sehingga tidak seperti mewakafkan makanan yang akan habis setelah dimakan; (b) yang diberi wakaf sudah jelas, bukan yang akan ada, sehingga tidak mungkin menyerahkan harta wakaf kepada orang yang belum lahir, sudah meniggal dunia, mesjid yang belum ada dan semacamnya; dan (c) barang yang diwakafkan bukan barang haram: tidak dibenarkan mewakafkan tempat perjudian atau tempat lokalisasi pelacuran atau semacamnya ${ }^{4}$.

Dilihat dari keberadaannya bahwa wakaf tanah berasal dari hukm Islam, yang diberlakukan sebagai hukum Nasional. Negara Republik Indonesia menganut asas Pancasila yang memberikan hak kepada rakyatnya untuk melaksanakan kiadah-kaidah yang sesuai dengan keyakinan agamanya. Menurut Ahmad Azhar Basyir menyatakan bahwa berlakunya UUD 1945 pasal 29 ayat 2 adalah negara menjamin kemerdekaan tiap-tiappendudukuntuk memeluk agamanya masingmasing dan beribadat menurut agamannya dan kepercayaannnya, maka secara yuridis formal hukum Islam berlaku bagi penduduk yang memeluk ajaran Islam 5 .

\footnotetext{
${ }^{2}$ Al-Syathbi, al-Muwafaqat, (Beirut: Dar al Fikr, 1985) Juz II, 4-6.

${ }^{3}$ Al-Dahlawi, Hujjah allah al-Bâlighah, (Beirut: Dar al-Fikr, 1986) Juz II, 116.

${ }^{4}$ Qadri A. Azizy, Membangun Fondasi Ekomoni Umat. (Yogyakarta: Pustaka Pelajar, 2004), 122.

${ }^{5}$ Ahmad Azhar Basyir, Hukum Islam tentang Wakaf Ijarah Syirkah, (Bandung: PT Al Ma'arif, 1973), 15.

220 JURNAL LISAN AL-HAL
} 
Perkembangan wakaf dapat diklasifikasikan kepada tiga fase, yaitu fase tradisional, semi-profesional dan profesional. Pertama, fase tradisional harta wakaf hanya untuk pembangunan fisik semata, seperti untuk pekuburan, mesjid, mushalla, dan madrasah. Pada fase ini ikrar wakaf umumnya hanya bersifat lisan tanpa ada bukti tertulis sama sekali. Akibatnya setelah diurus oleh beberapa generasi banyak harta wakaf yang hilang tanpa bekas. Kedua, fase semi-profesional adalah pengelolaan wakaf sudah mulai dikembangkan secara produktif tetapi belum maksimal. Pelaksanaan wakaf sudah mulai dilakukan secara tertulis dengan melalui Akta Ikarar Wakaf (AIW) yang dibuat oleh Pejabat Pembuat Akta Ikrar Wakaf (PPAIW). Model wakaf ini sudah memiliki kekuatan hukum. Ketiga, fase professional adalah wakaf sudah dikembangkan secara produktif. Bahkan wakaf dalam bentuk uang dan barang berharga lainnya sudah mulai diperkenalkan. Di Indonesia, wakaf uang diperkuat dengan UU No. 41 Tahun 2004 dan PP No. 42 Tahun 2006.

\section{B. Pendistribusian dan Pendayagunaan Wakaf}

Semangat yang dibawa bersama perintah wakaf adalah adanya perubahan kondisi seseorang dari mauquf 'alaih (penerima wakaf) menjadi wakif (pemberi). Bertambahnya jumlah wakif akan mengurangi beban kemiskinan yang ada di masyarakat. Namun keterbatasan dana wakaf yang berhasil dihimpun sangat terbatas. Hal mi menuntut adanya pengaturan yang baik sehingga potensi umat dapat dimanfaatkan secara optimal mungkin. Dan tidak bisa tidak diperlukan lembaga-lembaga yang khusus mengelola dana-dana wakaf ini secara profesional. Lembagalembaga pengelola wakaf dituntut untuk merancang program secara terencana dan terukur. Parameter keberhasilan yang digunakan lebih menitikberatkan pada efek pemberdayaan masyarakat bukan pada populis.Misalkan pengguliran program santunan pendidikan. Tugas para pengelola wakaf tidak berhenti pada pemberian santunan dana, tapi bagaimana upaya-upaya pemberdayaan memandirikan penerima beasiswa agar terbebas dan jerat kemiskinan. Bukan membiarkan dalam kemiskinan hingga terbiasa dan bangga serta menjadi komoditi. Selain perancangan program yang baik, lembaga-lembaga pengelola wakaf perlu melakukan skala prioritas program. Program yang harus diprioritaskan tentu saja program- program yang berefek luas dan jangka panjang, serta tepat pada akar permasalahan. Istilahnya, membunuh satu induk masalah yang berimbas pada matinya anak-anak masalah. Masyarakat miskin pun perlu dipilih yang potensial untuk dikembangkan. Artinya, suatu saat ia dapat membantu masyarakat miskin lainnya. Manfaat yang didapatkan

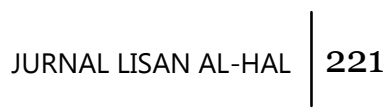


ketika selektif dalam memberi adalah terhindamya duplikasi atau penumpukan bantuan kepada mauquf 'alaih yang sama. Di samping itu, kesalahan dalam penyaluran bantuan relatif kecil karena adanya perencanaan dan kontrol yang ketat.

Pengetahuan tentang golongan-golongan masyarakat yang berhak menerima wakaf menjadi acuan, di samping bukti-bukti administratif, dan pembuktian aktif berupa investigasi. Dapat dilihat bahwa manajemen ini dapat menyelamatkan potensi dana wakaf yang ada di masyarakat. Salah satu fungsi wakaf adalah fungsi sosial sebagai sarana saling berhubungan sesama manusia terutama antara orang kaya dan orang miskin, karena dana wakaf dapat dimanfaatkan secara kreatif untuk mengatasi kemiskinan yang merupakan masalah sosial yang selalu ada dalam kehidupan masyarakat. Agar dana wakaf yang disalurkan itu dapat berdaya guna dan berhasil guna, maka pemanfaatannya harus selektif untuk kebutuhan konsumtif atau produktif. Masing-masing dan kebutuhan konsumtif dan produktif tersebut kemudian dibagi dua, yaitu konsumtif tradisional dan konsumtif kreatif, sedangkan yang berbentuk produktif dibagi menjadi produktif konvensional dan produktif kreatif.

1. Konsumtif Tradisional. Maksud pendistribusian wakaf secara konsumtif tradisional adalah bahwa wakaf dibagikan kepada mauquf 'alaih dengan secara Iangsung untuk kebutuhan konsumsi sehari-hari, seperti pembagian hasil wakaf sawah seperti, beras dan jagung kepada faqir miskin atau pembagian wakaf secara langsung oleh para wakif kepada mauquf 'alaih yang sangat membutuhkan karena kekurangan pangan dan mengalami musibah. Pola tersebut merupakan program jangka pendek dalam mengatasi permasalahan umat.

2. Konsumtif Kreatif. Pendistribusian wakaf secara konsumtif kreatif adalah wakaf yang diwujudkan dalam bentuk barang konsumtif dan digunakan untuk membantu orang miskin dalam mengatasi permasalahan sosial dan ekonomi. Bantuan itu antara lain seperti alat-alat sekolah dan beasiswa untuk para pelajar, bantuan sarana ibadah seperti sarung dan mukena, bantuan alat-alat pertanian untuk petani, perahu untuk nelayan, dan sebagainya.

3. Produktif konvensional. Pendistribusian wakaf secara produktif konvensional adalah wakaf yang diberikan dalam bentuk barangbarang produktif dengan menggunakan barang-barang tersebut, para mauquf 'alaih dapat menciptakan suatu usaha, seperti wakaf sapi kepada pelajar untuk diminum susunya atau dijual anaknya untuk keperluan asrama, wakaf domba untuk diambil bulunya, wakaf ayam,

$222 \mid$ JURNAL LISAN AL-HAL 
bebek, dan burung untuk diambil telurnya, wakaf hewan jantan untuk pengembangbiakan melalui perkawianan dengan hewan-hewan betina, pemberian bantuan ternak sapi perahan untuk diambil susunya atau membajak sawah, alat pertukangan, mesin jahit, dan sebagainya.

4. Produktif Kreatif. Pendistribusian wakaf secara produktif kreatif adalah wakaf yang diwujudkan dalam bentuk pemberian modal bergulir, baik untuk permodalan proyek sosial, seperti membangun sekolah, sarana kesehatan atau tempat ihadah maupun modal usaha untuk pengembangan usaha para pedagang atau pengusaha kecil.

Ada beberapa hambatan-hambatan dalam optimalisasi pendayagunaan wakaf yaitu: pertama, tidak adanya persamaan persepsi antar ulama tentang kedudukan wakaf dalarn hukum Islam, apakah wakaf itu termasuk bidang ta'abbudi (ibadah) ataukah termasuk bagian al-furudh al-ijtimaiyah (kewajiban sosial). Kedua, sebagian ulama beranggapan hahwa wakaf itu sekedar ritual seremonial, tidak ada kaitannya dengan ekonorni, sosial, dengan pengentasan kemiskinan. Sehingga pada akhirnya wakaf tidak potensi dalam meningkatkan ekonomi umat. Ketiga, banyak orang awam beranggapan bahwa sumber wakaf hanya terfokus pada benda bergerak yang hanya berupa tanah saja. Hal ini tidak akan memberi motivasi tinggi untuk berwakaf selain tanah, padahal tanah untuk zaman ini sulit sekali. Keempat, banyak yang beranggapan bahwa wakaf itu ibadah syakhsiyah atau ibadah pribadi yang tidak perlu campur tangan orang lain atau intervensi penguasa. Kelima, Badan Wakaf Indonesia (BWI) bersifat independen tidak resmi pemerintah, sehingga tidak berwibawa, sehingga dengan demikian menjadi tidak efektif dan efesein. Keenam, aparat pengelola wakaf bukan pegawai negeri, tetapi tenaga swasta. Padahal dalam negara-negara Islam sudah ada menteri wakaf, sepert Kuwait, Mesir, Syiria, dan Saudi Arabiyah.

\section{Sistem Pengawasan Dalam Pengelolaan Wakaf}

Pengawasan dapat didefinisikan sebagai proses untuk menjamin bahwa tujuan-tujuan organisasi dan manajemen tercapai. mi berkenaan dengan cara-cara membuat kegiatankegiatan sesuai dengan yang telah direncanakan sebelumnya Pengertian mi menunjukkkan adanya hubungan yang erat antara penncanaan dan pengawasanOleh karena itu, pengawasan mempunyai peranan atau kedudukan yang sangat penting dalam manajemen, karena mempunyai fungsi untuk menguji apakah pelaksanaan kenerja itu teratur, tertib, terarah atau tidak. 
Robert J. Mockler sebagaimana dikutip T. Handoko, mengatakan bahwa pengawasan manajemen adalah sutu usaha sistematik untuk menetapkan standar pelaksanaan dengan tujuan-tujuan pcrencanaan, merancang sistem informasi umpan balik, membandingkan kegiatan nyata dengan standar yang tclah ditetapkan sebelumnya, menentukan dan mengukur penyimpangan-penyimpangan, serta mengambil tindakan koreksi yang diperiukan untuk menjamin bahwa semua sumber daya perusahaan dipergunakan dengan cara paling efektif dan efisien ${ }^{6}$. Pengawasan dilakukan untuk menjamin jalannya kegiatan program sesuai dengan standar yang telah ditetapkan. Sesuai tidaknya amat tergantung pada niat dan kecakapan dan para pelaksana. Niat tulus tapi tidak cakap, kegiatan akan me- nyimpang. Sebaliknya meski cakap tapi dilandasi kepentingan tertentu, kegiatan juga akan menyimpang. Jika memang terjadi penyimpangan, analisa pengawasan harus dilakukan dengan jemih, tepat, dan obyektif. Analisa pengawasan hams sanggup mengungkap sebab-sebab penyimpangan. Karena itu tim pengawas yang ditugaskan, juga tidak boleh memiliki kepentingan yang akan menambah parahnya suatu penyimpangan? ${ }^{7}$.

Agar pengawasan dapat berjalan dengan baik dan efektif, maka harus mengikuti prinsip-prinsip pengawasan. Harold Koontz dan Cyril O'Donnell dalam bukunya Principle of Management sebagaimana dikutip Sukarta menyebut 14 macam prinsip sebagai berikut: Pertama, prinsip tercapainya tujuan. Maksudnya adalah bahwa pengawasan harus ditujukan terhadap tercapainya tujuan yaitu dengan mengadakan koreksi untuk menghindari penyimpangan-penyimpangan atau deviasi dan pada perencanaan.

Kedua, prinsip efesiensi pengawasan. Maksudnya adalah bahwa pengawasan efesien bilamana dapat menghindarkan penyimpanganpenyimpangan pada planning. Nazhir sebagi top manajeral harus hati-hati dalam melakukan amant mengelola dan mengembangkan wakaf. Pengawasan merupakan bentuk amar ma'ruf nahi munkar yang wajib dijalankan setiap muslim di manapun berada termasuk dalam masalah wakaf.

Ketiga, prinsip tanggung jawab. Maksudnya adalah bahwa pengawasan hanya dapat dilaksanakan apabila manajer bertanggung jawab penuh terhadap pelaksanaan perencanaan. Dalam ajaran agama Islam bahwa pertanggungjawaban nanti di akhirat di hadapan Allah Swt.

${ }^{6}$ Hani T. Handoko, Manajemen, (Yogykarta: BPEE cet. Ke-1. 1999), 359.

7 Eri Sudewo, Manajemen Zakat. (Jakarta: Insitut Manajemen Zakat, 2004), 148.

$224 \mid$ JURNAL LISAN AL-HAL 
Semua manusia memiliki tanggung jawab. Oleh karena itu nazhir harus bertanggung jawab secara horizontal ada wakif dan masyarakat dan vertikal pada Allah Swt.

Keempat, prinsip pengawasan terhadap masa yang akan datang. Maksudnya adalah bahwa pengawasan yang efektif harus ditunjukkan terhadap pencegahan penyimpangan planning yang akan terjadi baik pada waktu sekarang maupun yang akan datang.

Kelima, prinsip pengawasan langsung. Maksudnya adalah bahwa pengawasan dilakukan oleh manajer atas dasar bahwa manusia itu suka berbuat salah. Cara yang paling baik untuk menjamin adanya pelaksanaan yang sesuai dengan planning ialah mengusahakan sedapat mungkin para petugas memiliki kualitas yang bailk. Dalam hal ini, nazhir dalam mengelola wakaf harus memili planning yang sitematis dan stratigis, sehingga wakf berkembang dengan baik.

Keenam, prinsip refleksi perencanaan. Maksudnya adalah bahwa pengawasan harus disusun dengan baik sehingga dapat mencerminkan karakter dan susunan pada planning.

Ketujuh, prinsip penyesuaian dengan organisasi. Maksudnya adalah hahwa pengawasan harus dilakukan sesuai dengan struktur organisasi. Manajer dan bawahannya merupakan sarana untiik melaksanakan planning. Dengan demikian pengawasan yang efektif harus disesuaikan dengan luas autoriti manajer, sehingga mencerminkan struktur organisasi.

Kedelapan, prinsip kemandirian pengawas. Maksudnya adalah bahwa pengawasan harus sesuai dengan kebutuhan manajer. Teknik pengawasan harus ditunjukkan terhadap kebutuhan-kebutuhan akan informasi dan pada setiap manajer. Ruang Iingkup informasi yang dibutuhkan itu berbeda satu sama lain, tergantung kepada tingkat dan tugas dan pada manajer.

Kesembilan, prinsip standar . Maksudnya adalah bahwa pengawasan yang efektif dan efesien memerlukan standar yang tepat. Prinsip standar ini menghendaki bahwa setiap rencana itu mempunyai ukuran efektivitas yaitu untuk mengukur bahwa suatu program dan pada suatu rencana itu telah dilakukan. Hal ini dibutuhkan pengawasan terhadap pekerjaan itu dilakukan melalui orang-orang. Perlu diingat sekalipun manajer yang paling qualfied tidak dapat melepaskan diri dan pada pengaruh-pengaruh yang bersifat pribadi.

Kesepuluh, Prinsip pengawasan terhadap poin strategis. Maksudnya adalah bahwa pengawasan yang efektif dan efesien memerlukan adanya perhatian yang ditunjukan terhadap faktor-faktor 
yang strategis dalam pelaksanaan. Prinsip ini harus menceminkan kenyataan bahwa manajer itu tidak perlu meneliti sampai pada hal-hal yang sekecil-kecilnya dalam pelaksanaan perencanaan. Oleh karna itu manajer harus rnemusatkan perhatiannya terhadap faktor-faktor yang mungkin atau sedang menimbulkan penyimpangan-penyimpangan dan pada planning.

Kesebelas, Prinsip kekecualian. Maksudnya adalah bahwa efesiensi dalam pengawasan membutuhkan adanya perhatian yang ditujukan terhadap faktor kekecualian. Prinsip ini menunjukkan adanya kekecualian dan pada pembiasaan dalam pelaksanaan, sehingga manajer harus betulbetul memperhatikannya.OIeh karena hal ini dapat menimbulkan penyimpangan dan pada planning. Kekecualian ini dapat terjadi di dalam keadaan tertentu dimana situasi berubah atau tidak. Kedua belas, Prinsip daya-suai pengawasan. Maksudnya adalah bahwa pengawasan harus fleksibel untuk menghindarkan kegagalan planning.

Ketiga belas, prinsip peninjauan kembali. Maksudnya adalah hahwa sistem pengawasan harus ditinjau secara berkali-kali, agar supaya sistem yang digunakan berguna untuk mencapai tujuan.

Keempat belas, Prinsip tindakan. Maksudnya adalah bahwa pengawasan mengenai apabila ada ukuran-ukuran untuk mengoreksi penyimpangan-penyimpangan daripada planning, organizing, staffing dirrecting). Dalam Islam, pengawasan (control) paling tidak terbagi menjadi dua, yaitu: pertama, kontrol yang berasal dan diri sendiri yang bersumber dari tauhid dan keimanan keda Allah swt. Kcdua, kontrol dan luar. Pengawasan ini dilakukan dan luar diri sendini. Sistem pengawasanini dapat terdini atas mekanisme pengawasan dan pemimpin yang berkaitan dengan penyelesaian tugas yang telah didelegasikan. kesesuaian antara penyelesaian tugas dan perencanaan tugas dan lainlain ${ }^{8}$.

OIeh karena itu lembaga wakaf, Badan Wakaf (BWI) pada hakekatnya di dalamnya terdapat dua pengawasan substantif, yaitu:

a. Secara Fungsional, pengawasan telah built-in melekat inhern dalam diri setiap nazhir. Dengan pengawasan melekat, sejak dini penyimpangan telah dikikis tiap nazhir. Pengawasan melekat mi, secara tegas memposisikan nazhir menjadi penga was setiap program. Secara moral fungsi mi melegakan nazhir karena bisa bekeqa dan beribadah sekaligus. Secara tak langsunnazhir dipaksa dewasa, matang, dan

8 Didin Hafifuddin dan Hendri Tanjung, Manajemen Syariah dalam Praktek. (Jakarta: Gema Insani Press, 2003), 156.

226 JURNAL LISAN AL-HAL 
bertanggung jawab. Substansi inilah yang membedakannya dengan lembaga sosial umum lainnya.

b. Secara Formal, lembaga wakaf membuat Dewan Syariah. Kedudukan Dewan Syariah dilembagakan secara struktural. Bersifat formal disahkan melalui surat keputusan yang diangkat oleh Badan Pendiri. Karena mengawasi seluruh kegiatan, secara organisasi posisi Dewan Syariah berada di atas pimpinan lembaga wakaf. Hak dan wewenang Dewan Syariah adalah melegalisasi dan mengesahkan setiap program lembaga wakaf. Di samping itu, dewanini juga berhak menghentikan program yang menyimpang dan ketentuan syariah.

Mengingat namanya Dewan Syariah, maka dewan ini diisi oleh tim yang terdiri atas beberapa orang yang dianggap ahli di bidangnya. Dipimpin oleh Ketua Dewan Syariah yang diangkat berdasarkan kesepakatan anggota Dewan Syariah. Dewan Syariah inilah yang kemudian melakukan tiga macam pengawasan. Pertama, pengawasan syanah yang bersifat normatif, terutama dalam mengawasi kehidupan keseharian dengan memperhatikan nilai-nilai yang berkembang. Kedua, pengawasan manajemen syariah yang akan memantau apakah manajemen telah sesuai dengan prinsip syariah atau tidak. Manajemen yang bertentangan dengan syariah akan ditolak. Ketiga, pengawasan ekonomi syariah dengan memantau apakah pengelolaan dan pendayagunaannya telah dilakukan melalui pendekatan ekonomi syariah, karena wakaf yang dikelola tanpa landasan ekonomi syariah, maka manfaatnya tidak akan dirasakan oleh kalangan fakir miskin.

Teori POAC dari Gerorge R. Terry, yaitu: Planning (perencanaan), organizing (pengorganisasian), actuating (pelaksanaan), dan controlling (pengendalian). Gerorge R. Terry (1966) menjelaskan bahwa manajemen adalah proses yang khas yang terdiri atas tindakan-tindakan berupa perencanaan, pengorganisasian, pelaksanaan, dan pengendalian bidang masing-masing dengan menggunakan sain dan seni yang dilakukan secara berurutan untuk mencapai sasaran yang telah ditetapkan dengan memanfaatkan sumberdaya manusia dan sumber daya lainnya". Sedangkan menurut Robert Kreitner adalah "Management is the prosess of working with and through other to efctively achieve organisation objectives by evvicienly usinglimited resources in achingingenviroment"10. Menurut James A. Stoner (yaitu: "management is the prosess of planning, organozing,

9 Pandji Anoraga, Manajemen Bisnis, (Jakarta: Rineka Cipta. 2004), 109.

10 Robert, Kreitner. Management. (Boston: Honghton Mifflin Company, 1983), 8. 
leading, and controling the effort of oragisation member and of using all other organization resources to achieve stated organsational goold.

Menurut Sondang P. Siagian mengemukakan bahwa fungsi manajemen mencakup: 1. Perencanaan, 2. Pengorganisasian, 3. Pemotivasian, 4. Pengawasan, dan 5. Penilaian. Demikian pula Mondy dan Premeaux, mengatakan "The management process is said to consist of four funtion: planning, organizing, inpluencing and controlling". Sementara Menurut Handoko (t. th: 16) bahwa manajemen adalah seni untuk melaksanakan suatu pekerjaan melalui orang lain. Teori SWOT berasal dari Charles D. Pringle. SWOT adalah suatu metode analisis yang menperhatikan empat hal terkait dengan keadaan organisasi baik hubungan internal maupun eksternal. Empat hal tersebut adalah anlisis kekuatan, kelemahan, peluang, dan ancaman ${ }^{11}$.

Menurut Effendy bahwa hakekat dan ciri-ciri manajemen Islam ada enam sebagai berikut: Pertama, Manajemen berdasarkan akhlak yang luhur. Akhlak mulia merupakan nilai fundamental dalam ajaran Islam yang dibawa Nabi adalah menyempurnakan akhlak manusia. Oleh karena itu, para manajer dan nazhir harus mengamalkan akhlak mulia (jujur, amanah, cerdas, sabar, rendah hati, saling menghoramati, suritauladan, qana'ah, tanggung jawab, dan sebagainya). Segala tindakan dan keputusan harus berdasarkan etis moralitas yang bersumberdari al-Qur'an dan Hadis Nabi ${ }^{12}$.

Kedua, Manajemen terbuka. Manajemen dalam Islam adalah adanya transpansi (open minded). Karena jabatan dalam Islam merupakan amanah yang harus dipertanggung jawabkan secara horizontal dan vetikal. Hal itu sesuai firman Allah (Qs. 4: 58) "sesungguhnya Allah menyuruh kamu menyampaikan amanah kepada yangberhak menerimanya". Manajer muslim dan nazhir wakaf yang menjalankan menajemen Islam adalah orang yang memiliki sifat jujur dan terbuka setiap saat untuk diperiksa apa yang dikerjakannnya untuk organisasi atau lembaga wakaf dalam rangka kebaikan umat.

Ketiga, Manajemen yang demokratis. Konsekwensi dari sikap terbuka dalam manajemen, maka pengambilan keputusan atas musyawarah untuk kebaikan organisasi termasuk lembaga wakaf. Bahkan dengan musyawarah, setiap personil akan merasa bertanggungjawab dan

11 Charles D. Pringle, Stastgic Mangement Text and Cases. (Boston: Allen Y and Bacon, 1992), 97.

12 Effendy, Mochtar, EK., Manajemen suatu Pendekatan Berdasarkan Ajaran Islam. (Jakarta: Bhratara Karya Aksara, 1989), 28.

228 JURNAL LISAN AL-HAL 
memiliki komitmen dalam menjalankan semua keputusan. Firman Allah (Qs. 42: 38) "urusan mereka (diputuskan) dengan musyawarah antara mereka" dan (QS. 3:159) "dan bermusyawarahlah engakau dalam semua urusan". Dengan demikian, semakin tinggi keterlibatan anggota dalampengambilan keputusan, maka mereka semakin berdaya dalam menjalankan dan mendorong kepusan kerja. Dalam menjalankan suatu lembaga, seperti wakaf dengan musyawarah, akan melahirkan kepercayaan dan kinerja yang profesional, karena mereka terlibat langsung dalam pengambilan keputusan.

Keempat, Manajemen berdasarkan ilmiah. Dalam Islam setiap menjalankan pekerjaan harus berdasarkan pengetahuan dan kebenaran. Oleh karena itu, aktivitasorganisasi atau lemabaga (wakaf) harus berdasarkan pengetahuan atau kebenaran. Dalam firman Allah, "Dan janganlah kamu mengikuti apa yang kamutidak mempunyai pengetahuan tentangnya. Sesungguhnya pendengaran, penglihatan, dan hati semua itu akan diminta pertanggung jawabannya" (Qs. 17: 36).

Kelima, Manajemen berdasarkan tolong menolong. Salah satu ciri utama kehidupan muslim dalam masyarakat adalah hidup tolong menelong, karena pada prinsipnya manusia bersosial (zon politican atau dalam istilah Ibnu Kkaldun al-insân madani bi thab'ihi). Dalam al-Qur'an menjelaskan, "Dan tolong menolonglah kamu dalam kebajikan dan taqwa, dan jangan tolong menolong dalam berbuat dosa dan pelanggaran" (Qs. 2: 2).

Keenam, Manajemen berdasarkan perdamaian. Allah memerintahkan umat Islam agar menjaga perdamaian, sesuai dengan hakekat Islam yang berarti keselamatan dan kedamaian. Dalam segala aspek kehidupan, umat Islam harus mengamalkan perdamaian, termasuk dalam lembaga wakaf. Allah berfirman (Qs. 60: 8), "Allah tidak melarang kamu untuk berbuat baik dan berlaku adil terhadap oang-orang yang tiada memerangimu karena agama, dan tidak pula mengusir kamu negerimu. Sesungguhnya Allah menyukai orang-orang yang berlaku adil " dan (Qs. 16: 91), "dan tepatilah perjanjian dengan Allah apabila kamu berjanji dan janganlah kamu membatalkan sumpah-sumpahmu itu, sesuadah meneguhkannya, sedang kamu telah menjadikan Allah sebagai saksimu. Sesungguhnya Allah mengetahi apa yang kamu perbuat".

\section{Nazhir Profesional Sebagai Manajer Wakaf}

Ada beberapa ciri atau karakteristik profesi, yang juga berlaku dalam pekerjaan mengelola wakaf, jika pekerjaan ini (kerja-kerja nazhir) ingin dikategorikan sebagai profesi. Pertama, adanya keahlian dan 
ketrampilan khusus untuk bisa menjalankan sebuah pekerjaan dengan baik. Keahliaan dan ketrampilan khusus ini umumnya dimiliki dengan kadar, lingkup, dan tingkat yang melebihi keahlian dan ketrampilan yang dimiliki orang kebanyakan lainnya. Kaum profesional berarti harus lebih ahli dan terampil dalam bidang profesionya dari pada orang lain. Keahlian dan ketrampilan inibiasanya dimilikinya berkat pendidikan, pelatihan dan pengalaman yang diperolehnya selama bertahun-tahun. Bahkan pendidikan dan pelatihan itu (formal maupun informa) dijalaninya dengan tingkat yang sangat ketat dan keras. Pengetahun atau keahilan dan keterampilan ini memungkinkan orang yang profesional mengenalinya dengan cukup cepat dan tepat persoalan yang dihadapi bidang pekerjaannya serta solusinya yang tepat. Dengan kata lain, pengetahuan dan keterampilan mi memungkinkan seorang profesional menjalankan tugasnya dengan tingkat keberhasilan dan mutu yang paling baik. Karena itu, masyarakat pun lalu mempercayakan persoalan yang dihadapinya pada orang yang dianggapnya profesional.

Kedua, adanya komitmen moral yang tinggi. Komitmen moral ini biasanya dituangkan, khususnya untuk profesi yang luhur, dalam bentuk aturan khusus yang menjadi pegangan bagi setiap orang yang mengemban profesi yang bersangkutan. Aturan ini berlaku sebagai semacam kaidah moral yang khusus bagi orang-orang yang mempunyai profesi tersebut. Ia merupakan aturan main dalam menjalankan atau mengemban profesi tersebut, yang biasanya disebut sebagai kode etik. Ada dua sasaran pokok dan kode etik ini. (a) Kode etik bermaksud melindungi masyarakat (dalam wakaf berarti wakif dan publik) dan kemungkinan dirugikan oleh kelalaian, disengaja atau tidak, dan kaum yang mengaku profesional (nazhir). (b) Kode etik juga bertujuan melindungi profesi tertentu seperti nazhir wakaf dari prilaku bobrok orang-orang yang mengaku dirinya profesional dalam wakaf, kode etik ini ada dalam UU wakaf, aturan perundangan lain, dan aturan fiqh bagi para nazhir.

Ketiga, biasanya orang yang profesional adalah orang yang hidup dan profesinya. Biasanya, ia dibayar dengan gaji yang sangat tinggi sebagai konsekwensi dari pengerahan seluruh tenaga, fikiran, keahlian, dan ketrampilannya, karena hidupnya telah diperuntukan demi profesinya dan profesinyaa itu telah membentuk sebagai identitasnya yang tidak bisa dipisahkan. Seorang profesional menjadi dirinya berkat dan melalui profesinya.

Keempat, pengabdian kepada masyarakat. Adanya komitmen moral yang tertuang dalam kode etik profesi atau sumpah jabatan menyiratkan bahwa orang-orang yang mengembangkan profesi tertentu, khususnya 
profesi luhur, lebih mendahulukan dan mengutamakan kepentingan masyarakat dari pada kepentingan pribadinya, dalam fiqh aulawiyah disebutkan, "taqdim al-ihtimam al-jama'i 'ala al-ihtimam al-fard" (mendahulukan kepentingan orang dari kepentingan pribadi).

Kelima, pada profesi luhur biasa ada izin khusus untuk menjalankan profesi tersebut. Karena setiap profesi khususnya profesi lihur menyangkut kepentingan orang banyak, dan terkait dengan nilaiflilai luhur karena berupa keselamatan, keamanfaatan, kelangsungan hidup, kesehatan, dan sebaginya. kepentingan orang banyak diperlukan izin khusus. Izin khusus ini bertujuan untuk melindungi masyarakat dan pelaksanaan profesi yang tidak becus. Izin juga sesungguhnya merupakan tanda bahwa orang tersebut mempunyai keahlian, keterampilan, dan komitmen moral yang diandalkan dan dapat dipercaya. Dalam wakaf izin itu dikeluarkan KUA (Kantor Urusan Agama) dan saat ini oleh Badan Wakaf Indonesia (BWI).

Keenam, kaum profesional biasanya menjadi anggota dan suatu organisasi profesi. Beberapa yang hisa disebut adalah IDI (Ikatan Dokter Indonesia) untuk profesi dokter, LAI (Ikatan Akuntan Indonesia) untuk profesi akuntan, dan sebagainya. Saat ini dalam wakaf belum terjadi, tetapi kalau BWI sudah berdiri dan berjalan bisa terlaksana. Selain ciri di atas seorang profesional juga harus menjunjung tinggi prinsip keadilan dengan tidak melakukan tindakan diskriminasi dan prinsip otonomi. Yaitu prinsip untuk diberi kebebasan sepenuhnya dalam menajalankan dan mengembangkan profesinya, bisa melakukan inovasi dan kreasi tertentu yang berguna bagi profesi lembaga tempat ia bekerja. Secara umum, profesionalitas yang rnengharuskan adanya keahlian dan keterampilan dalam profesi sejalan dengan Islam. Alasannya karena al-Quran menyebut salah satu sifat Tuhan yang harus dicontoh oleh hambanya adalah khabir (ahli atau pakar) dan menekankan keharusan amanah. Dalam Islam, amanah berarti mampu menjalankan tugas yang diuerikafl dengan baik. Bahkan, dalam hadis riwayat Bukhari dan Abu Hurairah, Nabi bersabda: "Jika suatu urusan diserahkan kepada orang yang bukan ahlinya, tunggulah saatnya kehancurannya". Sedangkan keharusan adanya imbalan yang memadai yang membuat seorang profesional hidup layak sesuai dengan hadis Nabi: "Dari Abdillah bin Umar, Rasulullah Saw. Bersabda: "Berikanlah upah orang upahan sebelum kering keringatnya". (HR. Ibnu Majah dan Imam Thabrani).

Seorang profesional adalah seorang yang bekerja serius, disiplin, bertanggungjawab (amanah), dan mengandalkan keahlian serta keterampilan yang tinggi. karena itu profesinya melekat pada dirinya, 
dapat dijadikan sandaran hidup layak, dan dapat dipercaya masyarakat. Sementara itu, seorang nazhir secara bahasa adalah manajer. Sebab itu, dalam bahasa lain, bisa dikatakan nazhir profesional adalah manajer wakaf yang dalam mengelolanya mengacu pada prinsip-prinsip manajemen modern. Apa yang dimaksud manajer adalah subjek manajemen. Yaitu individu yang bertanggungjawab secara langsung untuk memastikan kegiatan dalam sebuah organisasi dijalankan bersama para anggotanya. Dalam ilmu manajemen, organisasi didefinisikan sebagai sekelompok orang yang bekerjasama dalam struktur dan koordinasi tertentu dalam mencapai serangkaian tujuan tertentu. Nazhir wakaf perorangan, apalagi nazhir organisasi dan badan hukum, karenanya, termasuk kategori organisasi. Dalam setiap organisasi, termasuk para nazhir wakaf, manajer bertugas untuk memastikan bahwa keseluruhan tujuan yang telah ditetapkan oleh organ isasi dapat diwujudkan melalui rangkaian kegiatan manjemen, baik yang bersifat fungsional maupun bersifat operasional. Allah menegaskan tentang imbalan ini dalam Qur'an, sebagai berikut: "Dan katakanlah : "Bekerjalah kamu, maka Allah dan Rasul-Nya serta orang-orang mu'min akan melihat pekerjaanmu itu, dan kamu akan dikembalikan kepada Allah Yang Mengetahui akan ghaib dan yang nyata, lalu diberikan-Nya kepada kamu apa yang kamu kerjakan." (At Taubah : 105).

Berdasarkan UU wakaf No 41/2004, tugas nazhir adalah: (1) melakukan pengadministrasian harta benda wakaf. (2). Mengelola dan mengembangkan harta benda wakafsesuai dengan tujuan, fungsi, dan peruittukannya. (3). Mengawasi dan melindungi harta benda wakaf. (4). amanah juga merujuk pada syarat pemimpin termasuk di dalamnya manajer, yang disebut al-Qur an (QS. 2826). Yakni, paling tidak memiliki dua kriteria: al-qawi (baik keterarmpilan intelektual, maupunemosiofnal, seperti kuat menghadapi resiko), dan al-amin (kuat terpercaya, kemampuan, dan etis memenej). Dalam ilmu manajemen, seorang manajer termasuk di dalarnnya nazhir harus memiliki keahlian manajemen (managerial skill) berikut:

1) Keahlian teknis (technical skill), yaitu keahlian yang diperlukan untuk melakukan pekerjaan spesifik tertentu, seperti pengoperasikan alat komputer, mendasain bangunan, membuat layout kantor, dan sebagainya

2) Keahlian berkomunikasi dan berinteraksi dengan masyarakat (human relation skill), yaitu keahlian dalam memaliami dan melakukan interaksi dengan berbagai jenis orang masyarakat 
3) Keahlian konseptual (conceptual skill), yaitu keahlian dalam berfikir secara abstrak dan sistematis. Keahlian ini terutama dibutuhkan oleh top manager, karena antara lain manyangkut visi dan misi, apalagi dalam wakaf

4) Keahlian dalam pengambilan keputusan (decision making skill), yaitu keahlian untuk mengidentifikasi masalah, sekaligus menawarkan berbagai alternatif solusi

5) Keahlian dalam mengelola waktu (time management skill), yaitu keahlian dalam memanfaatkan waktu secara efektif dan efesien.

Beberapa ahli manajemen lainnya menyebut syarat manajer, termasuk di dalamnya nazhir, adalah sebagai berikut: 1 . Cerdas, rasional, kreatif, responsif terhadap perubahan, kosmopolit dan visioner, 2. Komitmen pada etika (jujur, bertanggung jawab, dan moralitas), 3. Memiliki energi maksimal, 4. Mempu]emotional stabillity, 5. Menguasai the knowledge of human relation, 6. Personal motivation (inisiati), proaktif, antusias, dan percaya diri, 7. Mampu melakukan komunikasi sosial (perhatian, demokratis, dan transparan). Dalam al-Quran, "hendaklah kamu bermusyawarah dalam segala urusan", dan 8. Teaching ability (mampu mengabstraksi, mengidentifikasi masalah, dan berperan sebagai sumber informasi organisasi dan berani mengambil resiko yang terendah, dalam kaidah fiqh, "al-akhzu bi akhaf al-dlarurain" (mengambil kerusakan yang lebih ringan dari keduanya).

\section{E. Wakaf Sebagai Media Peningkatan Ekonomi}

Keberhasilan harta wakaf untuk pembangun tercatat dalam sejarah. Antara lain pada masa pemerintahan Khalifah Harun Al-Rashid. Puteri Zubaidah (istri Khalifah) pernah membangun jalan raya dari Baghdad di Irak sampai ke Mekkah. Jalan itu dibangun untuk memperlancar perjalanan jamaah yang akan menunaikan ibadah haji di Makkah. Dana pembangunan jalan raya tentunya tidaklah sedikit, mengingat jarak antara kedua kota relatif jauh. Seluruh biaya pembangunan berasal dari harta wakaf yang dikelola oleh Puteri.

Sedangkan pada masa pemerintahan Umanyah di Turki, dana wakaf berhasil meringankan perbelanjaan negara, terutama untuk menyediakan fasilitas pendidikan, sarana perkotaan dan fasilitas umum lainnya. Manakala di Mesir sudah semenjak lama harta wakaf dikelola, dan berhasil membangun Universitas Al-Azhar (Universitas tertua di dunia). Seluruh biaya operasional kegiatan Universitas mulai dari biaya mahasiswa (seluruhnya beasiswa), staf pengajar, pimpinan dan pengembangan Universitas berasal dari harta wakaf. 
Keberhasilan pengelolaan wakaf juga terjadi di negara sekuler Singapura. Dengan penduduk muslim minoritas (lebih kurang 453.000 orang saja) berhasil membangun harta wakaf secara inovatif. Majelis Ugama Islam Singapura (MUIS) melalui WARESS Investment Pte Ltd telah berhasil mengurus dan membangun harta wakaf secara profesional. Keberhasilan itu antara lain membangun apartement 12 tingkat bernilai sekitar S\$62.62 juta. WARESS juga berhasil membangun proyek perumahan mewah yang diberi nama The Chancery Residence, dan banyak lagi catatan aktivitas inovatif lainnya.

Perkembangan wakaf dapat diklasifikasikan kepada tiga fase, yaitu fase tradisional, semi-profesional dan profesional. Pertama, Fase tradisional harta wakaf diperuntukkan hanya untuk pembangunan fisik semata, seperti untuk pekuburan, mesjid, mushalla, dan madrasah. Pada fase ini ikrar wakaf umumnya hanya bersifat lisan tanpa ada bukti tertulis sama sekali. Akibatnya setelah diurus oleh beberapa generasi banyak harta wakaf yang hilang tanpa bekas. Kedua, fase semi-profesional adalah pengelolaan wakaf sudah mulai dikembangkan secara produktif tetapi belum maksimal. Pelaksanaan wakaf sudah mulai dilakukan secara tertulis dengan melalui Akta Ikarar Wakaf (AIW) yang dibuat oleh Pejabat Pembuat Akta Ikrar Wakaf (PPAIW). Model wakaf ini sudah memiliki kekuatan hukum. Ketiga, fase profesional adalah wakaf sudah dikembangkan secara produktif. Bahkan wakaf dalam bentuk uang dan barang berharga lainnya sudah mulai diperkenalkan. Di Indonesia, wakaf uang diperkuat dengan UU No. 41 Tahun 2004 dan PP No. 42 Tahun 2006. Namum, wakaf uang dalam kalangan pakar ilmu fiqh terjadi perbedaan pendapat, karena tidak ada satu teks yang menjelaskan secara langsung. Oleh karena itu, permasalahan wakaf uang termasuk ranah ijtihâdi atau furû' (cabang hukum Islam) yang dapat menyuburkan perbedaan pendapat.

Menurut Ibn Taimiyah bahwa peningkatan kesejahteraan meterial rakyat senantiasa merupakan hal yang paling penting, karena tanpa kesejahteraan material, maka kaum muslimin tidak dapat memperoleh kesejateraan spiritual. Negara memiliki tugas pokok untuk mensejahterakan rakyatnya baik meterial maupun spiritual, dimana keduanya tidak bisa dipisahkan. Tidak akan mungkin mereka taat beragama tanpa adanya pendukung utama berupa material. Sebab dalam pandangan Islam bahwa harta untuk manusia bukan manusia untuk harta, apalagi al-Quran menyebutkan harta sebanyak delapan puluh enam kali, sementara rasul dan nabi disebutkan tidak kurang dari delapan puluh kali. Oleh karena itu, menurut al-Maududi bahwa kepemilikan harta dalam

\footnotetext{
$234 \mid$ JURNAL LISAN AL-HAL
} 
Islam harus disertai dengan tanggung jawab moral. Dengan kata lain harta sebagai amanah Allah dan akan dipertanggungjawabkan nanti di akhirat.

Dalam hal ini Islam memandang, pertama, kesenjangan ekonomi akan menimbulkan hancurnya sendi-sendi perdaban dan tatanan sosial. Menurut Majdid berdasarkan surat al-Humazah, Islam memandang kejahatan terbesar setelah syirik adalah penumpukan kekayaan dan penggunaannya yang tidak benar ${ }^{13}$. Kedua, akumulasi kekayaan seseorang dibangun di atas keringat orang-orang miskin, karena di dunia ini tidak ada satu orang kaya dapat hidup berdiri sendiri tanpa orang-orang yang lemah ekonominya. Dalam hal ini wakaf sebagai bentuk tasyakkur (simbol ucapan terima kasih) orang kaya terhadap orang miskin.

Dalam bidang hak milik ekonomi, reformulasi tauhid dikaitkan dengan keadilan ekonomi dimunculkan oleh Bani Sadr dalam konsep implikasi aspek penegasian dan aspek positif untuk menciptakan keadilan ekonomi. Aspek penegasannya adalah bahwa dalam islam, tidak ada hak milik mutlak. Hak milik mutlak hanya milik Allah. Yang mendekati hak milik mutlak adalah hak milik masyarakat. Hak milik individu berada setelah hak milik masyarakat. Karenanya, berdasarkan pertimbangan tertentu, negara boleh melakukan nasionalisasi terhadap hak milik individu tertentu, bahkan mengambil alih hak milik individu muslim, ketika dia menolak untuk berzakat. Aspek positifnya adalah bahwa karena semuanya milik Allah, maka di hadapan Allah semua manusia sama, kecuali tingkat takwanya. Akibat dari konsep persamaan itu, maka islam melarang kesewenang-wenangan dan hubungan dominatif. Islam melarang untuk merampok hasil pekerjaan orang. Konsep tauhid Islam dalam konteks ekonomi merupakan pemersatu. Artinya, setiap individu sebagai bagian dari masyarakat dan setiap orang diperkenankan untuk mengembangkan pribadinya. Dengan konsep zakat dan waris sebagai doktrin yang diturunkan dari tauhid, Islam menghendaki pemerataan hasil pekerjaan. Kapitalisme ekstrim yang membolehkan penguasaan alat-alat produksi secara mutlak, yang karenanya melahirkan sikap main kuasa, menurut Bani Sadr, bertentangan dengan Islam ${ }^{14}$.

13 Noerchalish, Madjid, Nilai Identitas Kader dalam Pedoman LKI. (Ciputat: HMI Ciputat, 1993), 127.

14 Donohue, dan Esposito, John L. Islam dan Pembaharuan; Ensiklopedi MasalahMasalah, (Jakarta: Rajawali Pers, 1993), 423-424. 


\section{F. Wakaf sebagai Media Dakwah}

Praktek ritual menyembah tuhan yang dilakukan oleh manusia mendorong mereka untuk mendirikan bangunan tempat peribadatan. Dengan demikian, tempat-tempat itu didirikan dalam bentuk dan tempat yang permanen. Mereka memiliki kepedulian dan perhatian terhadap kelangsungan agama, maka mereka sukarela menyumbangkan sebagian tanah dan harta untuk kepentingan pembangunan tempat peribadatan. Sejarah mencatat bahwa praktek pembangunan tempat ibadah tersebut telah dilakukan oleh orang-orang Mesir dan Romawi. Masyarakat Mesir Kuno sudah terbiasa menyerahkan barang mereka yang dialokasikan untuk kepentingan para dewa, tempat peribadatan, dan pekuburan. Mereka mengelola barang tersebut untuk memperbaiki kuil-kuil dan kepentingan syiar agama mereka. Raja Ramses II telah menyerahkan kekayaan yang banyak terhadap pihak kuil Abidus.

Orang-orang Mesir telah mengenal sejenis wakaf keluarga (wakaf ahli) dan cara pengelolaannya. Seseorang menyerahkan kepemilikan penuh sebagian hartanya pada keluarga dan menjadikan keturunan dari keluarga tersebut sebagai pihak yang berhak memperoleh manfaat dari pengelolaan barang tersebut tanpa hak untuk memilikinya. Anak tertua merupakan orang yang paling berhak untuk mengelola harta tersebut ${ }^{15}$. Pada masa Fir`aun, sebagian penguasa dan orang kaya biasa menyerahkan tanah untuk bercocok tanam dan hasilnya diserahkan pada para tokoh spiritual yang pada saat itu dikenal dengan dukun, baik digunakan untuk kepentingan pribadi mereka, mendanai tempat peribadatan yang berada di bawah pengawasannya dan diberikan kepada fakir miskin ${ }^{16}$.

Fakta sejarah menunjukkan bahwa adanya perwakafan termasuk perwakafan tanah sejalan dengan penyebaran dakwah Islam dan pendidikan Islam. Wakaf sangat dibutuhkan sebagai sarana dakwa dan pendidikan Islam, seperti untuk kepentingan ibadah mahdhah (masjid, musolla, langgar, dam sebagainya), dan untuk ibadah ammah yang berkaitan dengan kepentingan masyarakat (bidang ekonomi, sosial, politik, dan sebagainya). Tanah yang diserahkan kepada pondok pesantren telah mampu meningkatkan eksistensi pondok pesantren ${ }^{17}$.

15 Muhammad Abid Abdullah Al-Kabisi, Hukum Wakaf, diterjemahkan oleh Ahrul Sani Fathurrohman (et.al.), (Jakarta: IIMaN Press, 2004), 15-16.

16 Mundzir Qahaf, Ekonomi Islam, Telaah Analitik terhadap Fungsi Sistem Islam, (Yogyakarta: Pustaka Pelajar, 1995), 4-5.

17 Suhadi, Imam, Wakaf Untuk Kesejahteraan Umat. (Yogyakarta: PT. Dana Bhakti Prima Yasa, 2002), 7.

$236 \mid$ JURNAL LISAN AL-HAL 
Menurut Hamzah Ya'qub bahwa media dakwah ada lima macam, yaitu: 1) Lisan adalah media dakwa yang peling sedrhana yang menggunakan lidah dan suara baik pidato maupun bimbingan, 2) Tulisan adalah media dakwah melalui tulisan, seperti buku, majalah, surat kabar, dan sebagainya, 3) Audiovisual adalah media dakwah yang dapat merangsang pendengaran, penglihatandan sebagainya, seperti televisi, film, internet, dan sebagainya, 4) Lukisan adalah media dakwah yang melalui gambar, karikatur, dan sebagainya, dan 5) Akhlak adalah media dakwah melalui perbuatan nyata yang mencerminkan ajaran Islam.

Secara garis besar bahwa meode dakwah ada tiga pokok, yaitu 18 :

1) Al-Hikmah adalah berdakwah dengan memperhatikan situasi dan kondisi dengan menitik beratkan kemampuan mereka, sehingga menerima ajaran Islam dengan merasa tidak terpaksa

2) Al-Mau'izhah hasanah adalah berdakwa berupa nsihat-nasihat atau menyampaikan Islam dengan rasa kasih sayang sehingga menyentuh hati mereka

3) Al-Mujadalah adalah berdakwah dengan bertukar pikiran dan menbantah dengan santun dan etis moral atau dengan dialogis yang bermoral agar kebenaran dapat diterima.

Dari diskripsi diatas, tidak menyebutkan dan menyentuh sama sekali media dakwah dengan harta. Padahal harta sangat efektif sekali dalam peningkatan dakwah Islam. Survey membuktikan bahwa banyak umat Islam menukar keimanannya dengan kekufuran karena kemiskinan. Hal itu sesuai dengan hadis Nabi, "kada al-faqr an yakun kufran" (hampir kefakiran akan terjerumus dalam kekufuran). Oleh karena sangat dibutuhkan media yang sangat efektif berupa harta benda sesuai dengan kebutuhan umat Islam. Sementara kebutuhan yang sangat urgen sekarang adalah harta benda untuk memenuhi kebutuhannya. Dalam pribahasa orang Arab, "suara perut lebih dahsyat dari suara hati". Harta sebagai wasilah atau media yang dapat mengantarkan pada tujuan pokok, yaitu kesejahteraan uman Islam, sebagaimana dlamkaidah fiqh, "li al-wasail alhukm al-maqashid" (tujuan hukum adalah memiliki media atau sarana).

Islam memberikan keleluasaan manusia untuk mengelola hartanya dan mengeluarkannya sebagai infak sesuai yang digariskan agama. Dalam al-Quran bahwa tujuan distribusi ekonomi antara lain terlihat dalam QS. Al-Dzariyat: 19 dalam kekayaan mereka terdapat hak bagi para pemintaminta dan yang terhalang. Tujuannya adalah agar harta kekayaan tidak $32-34$

18 Munir dan Wahyu Ilahi, Manajemen Dakwah. Jakarta: Rahmat Semesta, 2006), 
hanya beredar di kalangan orang kaya (QS. Al-Hasyr, 59: 7), ayat tersebut diperkuat oleh QS. Al-Taubah, 9: 60 bahwa sedekah baik yang wajib maupun yang sunnah seperti wakaf ditujukan untuk pemberdayaan dan pengentasan kemiskinan karena prioritas distribusinyaterhadap kelompok yang lemah (fakir miskin). Oleh karena itu, wakaf sebagai bentuk pembelanjaanharta di jalan kebaikan dan sebagai alternatif yang ditawarkan sebagai sarana mendekatkan diri kepada Allah swt. Menurut Mundzer Qahaf bahwa orang yang tidak memanfaatkan hartanya dalam produksi dan menyimpannya tanpa investasi akan kehilangan seperempatnya dalam waktu kurang dari 12 tahun ${ }^{19}$. Oleh karena itu Nabi bersabda: "perdagangkanlah harta anak yatim itu sehingga tidak habis termakan oleh zakat".

Tanah wakaf di Irak berasal dari peninggalan Umar ibn Khatthab. Tanah-tanah tersebut didayagunakan oleh Dewan Wakaf untuk kemaslahtan masyarakat, terutama yang membutuhkan, seperti pemberian beasiawa pada mahasiswa baik dalam negeri maupun luar negeri yang belajar di lembaga pendidikan milik Dewan Wakaf, pemberian tunjangan bulanan para imam, khatib, muadzin dan guru non formal, pemberian gaji pada ta'mir, pegawai atau karyawan, guru, dosen dan pengurus dewan wakaf, tunjangan pada anak yatim dan lanjut usi, dan pengobatan gratis ${ }^{20}$. Bahkan Dewan Wakaf Mesir mendanai biaya operasional dan biaya pembangunan lembaga pendidikan Islam swasta, antara lain Universitas al-Azhar dengan 21 fakultas yang ada, termasuk pemberian beasiswa kepada puluhan ribu mahasiswa asing berikut tempat tinggal mereka yang dikenal dengan "Madinah al-Bu'us alIslamiyah"21. Menurut Kuntowijoyo, people power menjelang Revolusi Islam Iran 1973 yang dipimpin oleh para ulama terjadi karena antara lain mereka memiliki sumber-sumber finansial yang independen, kekuatan dari zakat, dan wakaf yang terkait dengan masjid dan lembaga-lembaga pendidikan. Dengan demikian, wakaf telah menjadi sumber dan media kekuatan dakwah Islam yang sangat efektif dalam perjalanan sejarah peradaban Islam, "the only history will be judge" (hanya sejarahlah yang akan menjadi hakim penentu) 22.

\footnotetext{
${ }^{19}$ Mundzir Qahaf, Ekonomi Islam, Telaah Analitik terhadap Fungsi Sistem Islam, (Yogyakarta: Pustaka Pelajar, 1995), 80

20 Ibnu Taimiyah, Majmu' al-Fatawa. (Pakistan: Dar al-Wafa al-Taba'ah wa alNadhar, 2001), 14.

21 Al-Harani, Ibnu Taimiyah, Kitab al-Ikhtiyarat al-Ilmiyah. (Cairo: Matba'ah Kerdistan al-Ilmiyah, 1329 H), 118.

22 Kuntowijoyo, Identitas Politik Umat Islam. (Bandung: Mizan, 1997), 130.

$238 \mid$ JURNAL LISAN AL-HAL
} 


\section{G. Simpulan}

Dari diskripsi di atas, dapat disimpulkan bahwa wakaf merupkan ibadah yang mengandung suatu kemaslahatan yang tidak sama dengan sedekah-sedakah lainnya. Keistimewaan wakaf adalah bendanya bersifat permanen dan manfaatnya terus mengalir untuk kepentingan dakwah Islam dan peningkatan ekonomi umat Islam. Wakaf bukan hanya berupa benda tidak bergerak saja tetapi mencakup segala barang yang dapat diambil manfaatnya dan bendanya tidak habis sekali pakai. Hal ini sesuai sabda Nabi Saw, "tahanlah pokoknya dan sedekahkanlah hasilnya". Oleh karena itu, selama ini wakaf hanya dimenej secara tradisional saja, maka perlu penyegaran kembali (restorasi) agar wakaf menjadi profesional, sehingga manjadi aset yang potensial dan bermanfaat untuk kepentingan umat Islam. Wakaf dalam lintasan sejarah telah memberi kontribusi terhadap peradaban umat Islam. Wakaf sebagai media dakwah Islam, seperti masjid, musalla, perguruan tinggi, dan madrasah. Karena dengan lembaga tersebut akan menjadi syiar Islam yang rahmatal lil 'alamin. Wakaf juga memiliki fungsi sebagai media peningkatan ekonomi umat Islam, karena kebutuhan yang sangat urgen adalah harta untuk memenuhi kebutuhan hidup. Sementara yang dihadapi umat sekarang ini adalah kemiskinan. Salah satu mengentasnya adalah wakaf yang dimenej secara produktif dan profesional. Pada empat belas abad yang lalu, Nabi bersabda, "hampir kefakiran itu terjerumus pada kekafiran". Oleh karena itu perlu mengubah pola pikir atau menyegarkan kembali bahwa Islam tidaklah identik dengan kemiskinan dan keterbelakangan. Menurut Yusuf Qardhawi bahwa tidak selayak umat Islam hidup di negara Islam dalam kemiskinan walaupun orang kafir dzimmi (kafir yang dapat perlindungan di negara Islam).

\section{DAFTAR PUSTAKA}

Abdusalam, Izz bin, Qawa'id al Ahkam, Beirut: Dar al Fikr, 1985. Al-Dahlawi, Hujjah allah al-Bâlighah, Beirut: Dar al-Fikr, 1986.

Al-Harani, Ibnu Taimiyah, Kitab al-Ikhtiyarat al-Ilmiyah. Cairo: Matba'ah Kerdistan al-Ilmiyah, $1329 \mathrm{H}$.

Al-Kabisi, Muhammad Abid Abdullah, Hukum Wakaf, diterjemahkan oleh Ahrul Sani Fathurrohman (et.al.), Jakarta, IIMaN Press, 2004.

Al-Syathbi, al-Muwafaqat, Beirut: Dar al Fikr, 1985.

Al-Turmudzi, Muhammad bin 'Isa, Sunan al-Turmuzi, Kairo: Mauqi' Wizarah al-Auqaf al-Misriyyah, TT. 
Anoraga, Pandji, Manajemen Bisnis, Jakarta: Rineka Cipta. 2004.

Azizy, A. Qadri, Membangun Fondasi Ekomoni Umat. Yogyakarta: Pustaka Pelajar, 2004.

Basyir, Ahmad Azhar, Hukum Islam tentang Wakaf Ijarah Syirkah, Bandung: PT Al Ma'arif, 1973.

Charles D. Pringle, Stastgic Mangement Text and Cases. Boston: Allen Y and Bacon, 1992.

Donohue, dan Esposito, John L., Islam dan Pembaharuan; Ensiklopedi Masalah-Masalah, Jakarta: Rajawali Pers, 1993.

Effendy, Mochtar, EK., Manajemen suatu Pendekatan Berdasarkan Ajaran Islam. Jakarta: Bhratara Karya Aksara, 1989.

Hafifuddin, Didin dan Hendri Tanjung, Manajemen Syariah dalam Praktek. Jakarta: Gema Insani Press, 2003.

Handoko, T. Hani, Manajemen, Yogykarta: BPEE cet. Ke-1.

Ibnu Taimiyah, Majmu' al-Fatawa. Pakistan: Dar al-Wafa al-Taba'ah wa alNadhar, 2001.

James A. Stoner, Management, New Delhi: Prentice Hall of India Private Limited, 1986.

Kuntowijoyo, Identitas Politik Umat Islam. Bandung: Mizan, 1997.

Madjid, Noerchalish, Nilai Identitas Kader dalam Pedoman LKI. Ciputat: HMI Ciputat, 1993.

Munir dan Wahyu Ilahi, Manajemen Dakwah. Jakarta: Rahmat Semesta, 2006.

Qahaf, Mundzir, Ekonomi Islam, Telaah Analitik terhadap Fungsi Sistem Islam, Yogyakarta: Pustaka Pelajar, 1995.

Kreitner, Robert. Management. Boston: Honghton Mifflin Company, 1983.

Sudewo, Eri, Manajemen Zakat. Jakarta: Insitut Manajemen Zakat, 2004.

Suhadi, Imam, Wakaf Untuk Kesejahteraan Umat. Yogyakarta: PT. Dana Bhakti Prima Yasa, 2002. 